\title{
Potentiaali ja realiteetit kotimaisen valkuaistuotannon lisäämiseksi nyt ja tulevaisuudessa
}

Pirjo Peltonen-Sainio ${ }^{1)}$, Asko Hannukkala ${ }^{1)}$, Erja Huusela-Veistola ${ }^{1)}$, Liisa Voutila ${ }^{2)}$, Jarkko Niemi ${ }^{3)}$, Jarmo Valaja $^{4}$, Lauri Jauhiainen ${ }^{1)}$ ja Kaija Hakala ${ }^{1)}$

${ }^{1)}$ MTT Kasvintuotannon tutkimus, 31600 Jokioinen

${ }^{2)}$ MTT Hyvinkää, Tervamäentie 179, 05840 Hyvinkää

${ }^{3)}$ MTT Taloustutkimus, Latokartanonkaari 9, 00790 Helsinki

${ }^{4)}$ MTT Kotieläintuotannon tutkimus, 31600 Jokioinen

\section{Tiivistelmä}

Suomen kasviperäisen rehuvalkuaisen omavaraisuus on alhainen. Tulevaisuudessa valkuaistuotannon huoltovarmuuteen liittyvät haasteet korostuvat. Kotimaisen valkuaisomavaraisuuden parantaminen globaalimuutosten paineessa (OMAVARA) -hankkeen tavoitteena oli löytää kokonaisvaltaiset ratkaisut huolestuttavan alhaisen kasviperäisen rehuvalkuaisen omavaraisuuden merkittäväksi parantamiseksi. Arvioissa huomioitiin tuotantovarmuus ja siinä tapahtuvat muutokset, tuotantojärjestelmien kehittämistarve, vaihtoehtokasvien viljeltävyys ja alueellisuus, tuotetun kotimaisen valkuaisrehun käytettävyys soijan korvaajana ja kotieläinten tuotosvasteet verrattuna soijaan sekä viljelyn taloudellinen kannattavuus. Valkuaiskasvien tuotannon merkittävä lisääminen on mahdollista. Tuotantoalat voisivat hetimmiten kaksinkertaistua noin 200000 hehtaariin. Viljelyalan kestäviä laajentamismahdollisuuksia arvioitaessa huomioitiin valkuaiskasvien viljelykiertovaatimukset sekä alueelliset erot ilmastoriskeissä samoin kuin peltojen ja maalajien soveltuvuudessa. Vuosisadan puoliväliin mennessä, ilmaston lämmettyä valkuaiskasvien viljelyalat voisivat edelleen kaksinkertaistua. Pohjoisten viljelyalueiden rooli kasvaisi. Kokonaissadot kasvaisivat viljelyaloja enemmän, koska satoisampien palkoviljojen viljely lisääntyisi öljykasveja enemmän. Viljelyalojen vauhdikkaimman kasvun aikaan hehtaarisatojen ei ennakoitu nousevan. Silti kasviperäisen rehuvalkuaisen omavaraisuus parantuisi merkittävästi. Kotimainen öljykasvien tuotanto kattaa nykyisellään noin neljänneksen tarpeesta. Jos rypsialat nousisivat nykyiseen realistiseen potentiaaliinsa, noin 120000 hehtaariin, rypsivalkuaisen omavaraisuus voisi nousta kolmannekseen. Toisaalta vuosisadan puolivälissä, noin 200000 potentiaalisen hehtaarin myötä rypsiomavaraisuutemme olisi jo reilu 60 prosenttia. Rypsi ja rapsi sopivat korvaamaan tuontisoijan valkuaista palkoviljoja paremmin, mutta peltoalan kasvattaminen merkittävästi yli 120 000 hehtaarin tarkoittaisi sopivien peltojen rajallisuuden takia viljelykierron tihentymistä ja kasvintuhoojariskien lisääntymistä. Myös palkoviljojen tuotannon merkittävällekin laajentamiselle on sija. Soijarouhetta tuodaan Suomeen noin 180 miljoonaa kiloa vuodessa. Realistisen potentiaalin toteutuessa, ilman hehtaarisatojen nousua, voisimme jo nyt tuottaa palkoviljoja 180 miljoonaa kiloa, mutta peräti 400 miljoonaa kiloa vuosisadan puolivälissä. Soijarouheen ollessa erittäin valkuaisrikasta rehua nykyinen tuontimäärä vastaa noin 70 miljoonaa valkuaiskiloa. Palkoviljamme yltäisivät nykypotentiaalillaan noin 40-50 miljoonaan valkuaiskiloon riippuen millainen tasapaino herneen ja valkuaisrikkaamman härkäpavun välillä vallitsisi. Ilmaston lämpenemisen myötä jo aivan lähivuosikymmeninä soijavalkuainen voitaisiin teoriassa kokonaan korvata kotoisilla palkoviljoilla. Yksimahaisilla korvattavuus ruokinnassa tulee kuitenkin kynnyskysymykseksi. Pääpaino viljelyn lisäämisessä tulisikin asettaa herneelle, kunnes kasvinjalostus on tuottanut haitta-aineettomia härkäpapulajikkeita.

\section{Asiasanat}

herne, härkäpapu rapsi, rypsi, rehu, valkuainen, tuotanto, tuotantokyky, potentiaali, omavaraisuus 


\section{Johdanto}

Euroopan Unionin kasviperäisen rehuvalkuaisen omavaraisuus on enintään $30 \%$. Vaikka EU:n valkuaisen tuotanto on kaksi ja puolikertaistunut, on myös valkuaisen kysyntä lähes kaksinkertaistunut viimeisten 30 vuoden aikana (http://www.grainlegumes.com). EU:ssa valkuaisomavaraisuus vaihtelee maittain, riippuen niin viljelykasvien tuotantomahdollisuuksista ja viljelyn monipuolistamisen kannustimista kuin kotieläintuotannon muodoista. Ranska on EU:n omavaraisin (45\%) valkuaisen tuottaja, kun taas esimerkiksi Espanja tuo neljä viidennestä käyttämästään rehuvalkuaisesta (Anon. 2007). Myös Suomi kuuluu omavaraisuudeltaan heikompiin maihin. EU:n heikosta omavaraisuudesta kielii myös se, että $65 \%$ runsaasti valkuaista sisältävistä rehuraaka-aineista on soijaa, mutta EU tuottaa itse vain $2 \%$ tästä soijasta. Aminohappokoostumuksensa vuoksi soija on mm. sikarehujen tärkein valkuaislähde. Rapsirouheen osuus kasviperäisestä rehuvalkuaisesta on $12 \%$ ja auringonkukan $5 \%$, kun palkokasvien osuus jää alle $4 \%$ (Anon. 2007).

Rehuvalkuaisen riittävyys on haavoittuvainen ja riskialtis ruoantuotantomme lenkki. Saatavuuden ja hinnan lisäksi tuontiin liittyy merkittäviä rehu- ja ruokaturvallisuusriskejä, kuten salmonellatartunnan mahdollisuus. Myös geenimuunneltujen kasvien hyväksyttävyys rehuna puhuttaa edelleen. Tulevaisuudessa valkuaistuotannon huoltovarmuuteen liittyvät haasteet korostuvat: elintason noustessa maailman väkirikkaimmilla alueilla lihankulutus kasvaa samaan aikaan kun ilmastonmuutos kurittanee merkittäviä soijan tuotantoalueita. Ilmastonmuutokseen sopeutuminen maa- ja elintarviketaloudessa (ILMASOPU) -hankkeen tutkimusten perusteella Suomen kyky tuottaa niin öljy- kuin palkokasveja, mutta myös valkuaispitoisempia viljoja, paranee tulevaisuudessa. Tämä edellyttää, että sopeudumme ilmastonmuutoksen mukanaan tuomiin haasteisiin (Peltonen-Sainio ym. 2009, Hakala ym. 2011, Olesen ym. 2011, Peltonen-Sainio ym. 2011a, Trinka ym. 2001). Suomen pitkästä päivästä johtuen soijapavun viljely ei ole mahdollista tulevaisuudessakaan, vaan tuotantomme perustunee pääosin rapsiin, rypsiin, herneeseen ja härkäpapuun. Valkuaisen lisäksi nämä kasvilajit tuottavat tyypillisesti rinnakkaistuotteita, joita ovat öljykasveilla ruokaöljy ja biodiesel sekä palkokasveilla typpilannoitusvaikutus.

Valkuaisomavaraisuuden lisääminen on merkittävä haaste sekä luomu- että tavanomaisessa tuotannossa. Luomutuotannossa $100 \%$ nautojen rehuista on oltava luomutuotettua rehua. Parin vuoden päästä sama vaatimus on tulossa yksimahaisillekin. Luomuvalkuaisrehun saatavuus on kuitenkin heikko. Lisäksi valkuaisrehun hinta on merkittävä kustannustekijä sekä luomu- että tavanomaisessa kotieläintuotannossa. Esimerkiksi tavanomaisessa lihasikojen kasvatuksessa valkuaisrehun osuus on noin kolmannes rehukustannuksista. Suomalaisen kotieläintuotannon kilpailukyvyn kannalta onkin tärkeää varmistaa, että saatavilla on riittävästi hyvälaatuista ja kohtuuhintaista valkuaisrehua. Valkuaisomavaraisuus on merkittävä huoltovarmuusongelma jo nyt, mutta sen merkitys lisääntynee tulevaisuudessa. Itse huoltovarmuus-käsitteen tulkinta on muuttunut aikojen saatossa ja tämän päivän suurimpina huoltovarmuusriskeinä pidetäänkin luonnon olosuhteiden aiheuttamia laajoja katastrofeja (ml. ilmastonmuutos).

\section{Tutkimuksen tavoitteet}

Hankkeen tavoitteeksi asetettiin 1) löytää kokonaisvaltaiset keinot ja rakentaa ratkaisut nykyisellään huolestuttavan alhaisen kasvi-peräisen rehuvalkuaisen omavaraisuuden merkittäväksi parantamiseksi ottaen huomioon tuotantovarmuus (viljelyn riskien hallinta) ja siinä tapahtuvat muutokset, tuotantojärjestelmien kehittämistarve (ml. tuotannon suunnittelumallit), vaihtoehtokasvien viljeltävyys ja alueellisuus, tuotetun kotimaisen valkuaisrehun käytettävyys soijan korvaajana ja kotieläinten tuotosvasteet verrattuna soijaan sekä viljelyn taloudellinen kannattavuus ja kotimaisen valkuaisrehun vaikutus koti- 
eläintuotannon taloudelliseen ylijäämään sekä 2) tehdä tarkastelut kolmella aikajänteellä: nykyhetki, pari lähintä vuosikymmentä ja mahdollisuuksien puitteissa vuosisadan puoliväli.

\section{Tutkimusmenetelmät}

Kotimaisen valkuaisomavaraisuuden parantaminen globaalimuutosten paineessa (OMAVARA) -hanke hyödynsi olemassa olevan julkaistun tiedon sekä MTT:n laajat tieto- ja tutkimusaineistot sekä muut hyödynnettävissä olevat tilastoaineistot (erityisesti Boreal Kasvinjalostus Oy:n jalostusaineistot). Hanke arvioi valkuaisomavaraisuuden tuotantopotentiaalin sekä analysoi tämän toteutumismahdollisuuksia. Hankkeen tarkasteluissa otettiin huomioon sekä tavanomainen että luomutuotanto. Lisäksi tarkastelimme maailmanlaajuisia muutosennusteita soijan ja muiden keskeisten valkuaiskasvien tuotannossa lähivuosikymmeninä (2020- ja 2050-luvut) ja arvioimme todennäköisimpiä tuotantokyvyn ja tuotannon alueellistumisen kehityssuuntia Euroopassa ja Suomessa. Tässä kirjoituksessa keskitytään erityisesti valkuaiskasvien tuotantokyvyn lisäämispotentiaalin tarkasteluun.

\section{Vaihtoehtoiset valkuaiskasvit ja valkuaisrikkaat viljat}

Viljelyn monimuotoistamisen tulisi tapahtua suomalaisittain jo tuttujen, kasvinjalostuksen piirissä parhaillaankin olevien lajien myötä. Näitä ovat erityisesti rypsi, rapsi, herne ja härkäpapu. Tuntumaa muiden lajien viljelystä ja rehuominaisuuksista saataneen eritoten valkuaisrehuja vähemmän krantusti nauttivien märehtijöiden ruokintatutkimusten yhteydessä. Eksotiikkaan ei kuitenkaan lajivalinnassa kannata satsata, kun tavoitellaan nopeita tuloksia.

Pitkäaikaisaineistoihin perustuvat tutkimuksemme osoittivat, että öljykasveista rapsi tuotti rypsiä enemmän valkuaissatoa hehtaaria kohti. Valitsemalla jalostuksessa rapsi- ja rypsilinjoja, jotka ovat nykyistä valkuaispitoisempia, laski siemenen öljypitoisuus. Nämä tekijät puolestaan kytkeytyivät heikkosatoisuuteen ja siten runsasöljyisiä linjoja heikompaan valkuaissatoon (Peltonen-Sainio ym. 2011b). Siten kasvinjalostus ei voi tulevaisuudessa pyrkiä parantamaan rypsin ja rapsin valkuaistuotantoa luopumalla öljypitoisuudesta valkuaispitoisuuden hyväksi.

Kevätviljojen linja-aineistossa oli selvästi suurempaa sadon ja valkuaissadon vaihtelua kuin kaupallisilla lajikkeilla. Parhaat viljalinjat yhdistivät satoisuuden korkeaan jyvävalkuaiseen ilman haitallisia kytköksiä muihin agronomisiin ominaisuuksiin (Peltonen-Sainio ym. 2012a). Viljojen proteiinisatoja voidaan valinnalla parantaa merkittävästi, jopa vastaamaan herneen ja öljykasvien hehtaarikohtaisia proteiinituotoksia. Kasvinjalostuksella onkin tärkeä rooli parannettaessa viljojen valkuaissatoja samoin kuin eri viljojen, öljykasvien ja palkoviljojen satovarmuutta (Peltonen-Sainio ym. 2011c). Vaihtelu valkuaissadoissa oli tyypillisesti suurempaa valkuaiskasveilla kuin viljoilla (Peltonen-Sainio 2011). Valkuaiskasvien proteiinisadoissa ilmennyt vaihtelu ei kuitenkaan ole Suomessa systemaattisesti suurempaa kuin muun Euroopan merkittävimmillä tuotantoalueilla. Sen sijaan Suomessa vehnän valkuaissadot vaihtelevat merkittävästi muuta Eurooppaa enemmän.

\section{Valkuaisomavaraisuuden lisäämisen mahdollisuudet}

Kansallinen valkuaisomavaraisuutemme on ollut parhaimmillaankin vain noin viidenneksen tarpeesta. Suomesta ei voi tulla täysin valkuaisomavaraista, mutta valkuaisen tuotantoa voidaan merkittävästi tehostaa (Peltonen-Sainio ym. 2012b). Valkuaistuotannon lisäksi on myös hyvä muistaa, että valkuaiskasvit tuottavat monipuolisesti ekosysteemipalveluja, mikä osaltaan tukee viljelyn laajentamista (Peltonen-Sainio 2012). Valkuaiskasvien tuotantoalat voisivat hetimmiten kaksinkertaistua noin 200000 hehtaariin, kun viljelyalan kestävä laajentaminen huomioi valkuaiskasvien viljelykiertovaatimukset sekä alueelliset erot ilmastoriskeissä samoin kuin peltojen ja maalajien soveltuvuudessa. Vuo- 
sisadan puoliväliin mennessä, ilmaston lämpenemisen myötä valkuaiskasvien viljelyalat voisivat edelleen kaksinkertaistua, lähestyen jopa 400000 hehtaaria. Tällöin nykyisin rajallisesti valkuaiskasvien tuotantoon valjastettujen pohjoisten viljelyalueiden rooli kasvaisi. Kokonaissadot kasvaisivat viljelyaloja enemmän, koska nykyisellään marginaalikasveiksi luokiteltavien palkoviljojen viljely lisääntyisi öljykasveja enemmän ja ne ovat myös satoisampia. Toisaalta on huomattava, että rypsi ja rapsi sopivat palkoviljoja paremmin korvaamaan tuontisoijan valkuaista, mutta öljykasvien peltoalan kasvattaminen yli 120000 hehtaarin tarkoittaisi sopivien peltojen rajallisuuden takia kestävyydestä tinkimistä, viljelykiertojen tihentymistä ja kasvintuhoojariskien kasvua. Viljelyalojen vauhdikkaimman kasvun aikaan hehtaarisatojen ei oletettu nousevan (Peltonen-Sainio ym. 2012b).

Kotimainen tuotanto kattaa nykyisellään noin neljänneksen rypsivalkuaisen tarpeesta (PeltonenSainio ym. 2012b). Jos rypsialat nousisivat nykyiseen realistiseen potentiaaliinsa, noin 120000 hehtaariin, rypsivalkuaisen omavaraisuus voisi nousta kolmannekseen. Toisaalta vuosisadan puolivälissä, ilmaston lämmettyä, noin 200000 potentiaalisen hehtaarin myötä rypsiomavaraisuusasteemme olisi jo reilu 60 prosenttia. Omavarainen rypsintuottaja Suomesta tulisi vain, jos rypsiperäisen rehuvalkuaisen tarve laskisi 40-50 prosentilla nykyisestään tai hehtaarisadot kasvaisivat viljelyalan kasvusta huolimatta.

Myös palkoviljojen tuotanto voi laajeta merkittävästi. Soijarouhetta tuodaan Suomeen noin 180 miljoonaa kiloa vuodessa. Realistisen potentiaalin toteutuessa (ilman hehtaarisatojen nousua) voisimme jo nyt tuottaa palkoviljoja samaiset 180 miljoonaa kiloa, ja peräti 400 miljoonaa kiloa vuosisadan puolivälissä. Soijarouheen ollessa erittäin valkuaisrikasta rehua nykyinen tuontimäärä vastaa noin 70 miljoonaa valkuaiskiloa. Palkoviljamme yltäisivät nykypotentiaalillaan noin 40-50 miljoonaan valkuaiskiloon riippuen millainen tasapaino herneen ja valkuaisrikkaamman härkäpavun välillä vallitsisi. Ilmaston lämpenemisen myötä soijavalkuainen voitaisiin teoriassa kokonaan korvata kotoisilla palkoviljoilla. Yksimahaisilla soijan korvattavuus ruokinnassa tulee kuitenkin kynnyskysymykseksi. Pääpaino viljelyn lisäämisessä tulisikin asettaa herneelle, kunnes kasvinjalostus on tuottanut haittaaineettomia härkäpapulajikkeita. Tavoiteltaessa tuontisoijan korvaamista yksimahaisten ruokinnassa, viljelyn monimuotoistamisen tulisi tapahtua suomalaisittain jo tuttujen, kasvinjalostuksen piirissä parhaillaankin olevien lajien myötä. Tuntumaa muiden lajien viljelystä ja rehuominaisuuksista saataneen ennemminkin valkuaisrehuja monipuolisemmin nauttivien märehtijöiden myötä. Eksotiikkaan ei kannata satsata, jos halutaan nopeita tuloksia.

\section{Kirjallisuus}

Anon. 2007. European Feed Manufacturers Federation FEFAC. Feed and Food Statistical Yearbook 2007.84 s. Hakala, K., Hannukkala, A., Huusela-Veistola, E., Jalli, M \& Peltonen-Sainio, P. 2011. Pests and diseases in a changing climate: a major challenge for Finnish crop production. Agricultural and Food Science 20: 3-14.

Olesen, J.E., Trnka, M., Kersebaum, K.C., Skjelvåg, A.O., Seguin, B., Peltonen-Sainio, P., Rossi, F., Kozyra, J. \& Micale, F. 2011. Impacts and adaptation of European crop production systems to climate change. European Journal of Agronomy 34: 96-112.

Peltonen-Sainio, P., Jauhiainen, L., Hakala, K. \& Ojanen, H. 2009. Climate change and prolongation of growing season: changes in regional potential for field crop production in Finland. Agricultural and Food Science 18: 171-190.

Peltonen-Sainio, P., Jauhiainen, L., Trnka, M., Olesen, J.E., Calanca, P.L., Eckersten, H., Eitzinger, J., Gobin, A., Kersebaum, C., Kozyra, J., Kumar, S., Marta, A.D., Micale, F., Schaap, B., Seguin, B., Skjelvåg, A.O. \& Orlandini, S. 2010. Coincidence of variation in yield and climate in Europe. Agriculture, Ecosystems and Environment 139: 483-489. 
Peltonen-Sainio, P., Jauhiainen, L., Hyövelä, M. \& Nissilä, E. 2011b. Trade-off between oil and protein in rapeseed at high latitudes: means to consolidate protein crop status? Field Crops Research 121: 248-255.

Peltonen-Sainio, P., Jauhiainen, L. \& Sadras, V.O. 2011c. Phenotypic plasticity of yield and agronomic traits in spring cereals and rapeseed at high latitudes. Field Crops Research 124: 261-269.

Peltonen-Sainio, P. 2012. Protein crop production at the northern margin of farming: To boost, or not to boost, that is the question. Food Security, korjattu.

Peltonen-Sainio, P., Jauhiainen, L. \& Nissilä, E. 2012a. Improving cereal protein yields for high latitude conditions. European Journal of Agronomy, korjattavana.

Peltonen-Sainio, P., Hannukkala, A., Huusela-Veistoja, E., Niemi, J., Voutila, L., Vajala, J., Jauhiainen, L. \& Hakala, K. 2012b. Potential and realities for enhancing crop based protein production in northern conditions. Food Security, arvioitavana.

Trnka, M., Olesen, J.E., Kersebaum, K.C., Skjelvåg, A.O., Eitzinger, J., Seguin, B., Peltonen-Sainio, P., Rötter, R., Iglesias, A., Orlandini, S., Dubrovský, M., Hlavinka, P., Balek, J., Eckersten, H., Cloppet, E., Calanca, P., Gobin, A., Vucetic V., Nejedlik, P., Kumar, S., Lalic, B., Mestre, A., Rossi, F., Kozyra, J., Alexamdrov, V., Semerádová, D. \& Zalud, Z. 2011. Agroclimatic conditions in Europe under climate change. Global Change Biology 17: 2298-2318. 